\title{
Revision of species delineation in the genus Ectothiorhodospira
}

\author{
Stefano Ventura, Carlo Viti, Roberta Pastorelli and Luciana Giovannetti
}

Centro di Studio dei Microrganismi Autotrofi, CNR, and Dipartimento di Scienze e Tecnologie Alimentari e Microbiologiche, Sezione Microbiologia Applicata, Università di Firenze, piazzale delle Cascine 27 50144 Firenze, Italy
Author for correspondence: Stefano Ventura. Tel: +39055 350542. Fax: + 39055330431. e-mail: ventura@csma.fi.cnr.it

When the type strains and other strains of the six currently defined species of the genus Ectothiorhodospira were examined by DNA-DNA reassociation and RFLP of 16S/23S rDNA (ribotype), only four genospecies could be found. The possibility of defining taxonomically meaningful species corresponding to these four genospecies was investigated by combining DNA relatedness and ribotype data with other genotypic and phenotypic characters already described in the literature, an approach known as polyphasic taxonomy. Following this comparison, the type strain and another strain of Ectothiorhodospira vacuolata were found to be very similar to the type strain of Ectothiorhodospira shaposhnikovii and have been transferred to this latter species. Also, the type strain of Ectothiorhodospira marismortui and another previously unidentified strain were found to be very similar to the type strain of Ectothiorhodospira mobilis and have been transferred to this latter species. Due to the limited degree of reciprocal DNA relatedness, strains belonging either to Ectothiorhodospira marina or to Ectothiorhodospira haloalkaliphila are still considered as belonging to separate species, even though they show a remarkable phenotypic similarity. This revision has led to the delineation of only four species in the genus Ectothiorhodospira, namely E. mobilis, $E$. shaposhnikovii, E. marina and E. haloalkaliphila. E. vacuolata is recognized as a junior synonym of $E$. shaposhnikovii and $E$. marismortui as a junior synonym of E. mobilis.

Keywords: Ectothiorhodospira, phototrophic purple bacteria, taxonomy, DNA-DNA reassociation, ribotype

\section{INTRODUCTION}

The anoxygenic purple phototrophic bacteria belonging to the family Ectothiorhodospiraceae have been the subject of several taxonomic studies. Initially (Pelsh, 1937; Raymond \& Sistrom, 1969; Trüper, 1968), these bacteria were recognized as members of a single genus, Ectothiorhodospira, belonging to the family Chromatiaceae (anoxygenic purple sulfur bacteria). Later, on the basis of $16 \mathrm{~S}$ rRNA analysis and phenotypic properties, the family Ectothiorhodospiraceae was described for the genus (Imhoff, 1984a). Strains of the Ectothiorhodospiraceae produce external globules of elemental sulfur during photosynthetic sulfide oxidation, live in saline environments at alkaline $\mathrm{pH}$ and possess stacks of intracytoplasmic membranes (Imhoff, 1989). Recently, two distinct genera, Ectothiorhodospira and Halorhodospira, have been described in this family on the basis of phylogenetic evidence gathered from 16S rDNA sequence analysis and coherent physiological properties (Imhoff \& Süling, 1996). Less halophilic species belong to the genus Ectothiorhodospira, while highly halophilic species have been assigned to the genus Halorhodospira. At the same time, a few misclassified strains were assigned to two new species of Ectothiorhodospira. At this time, no further investigations have been carried out on the interspecific relationships in either genera of the family Ectothiorhodospiraceae, even if rDNA sequence analysis showed the existence of clusters of tightly related species.

Since rDNA sequence analysis lacks the necessary resolution for the determination of taxonomic relationships between highly related micro-organisms, as repeatedly stated (Fox et al., 1992; Stackebrandt \& Goebel, 1994; Clayton et al., 1995), these latter relationships should be investigated at the genome 
level by the application of a more discriminating approach like DNA-DNA hybridization (Stackebrandt \& Goebel, 1994; Stackebrandt \& Liesack, 1993). After extensive application to diverse bacterial groups and comparison with phenotypic characters, a lower limit of $70 \%$ DNA relatedness has been indicated for strains belonging to the same species (Wayne et al., 1987), but a stable and reliable delineation of bacterial species should be obtained through a combination of genotypic and phenotypic properties, an approach known as polyphasic taxonomy (Murray et al., 1990; Vandamme et al., 1996). In the family Ectothiorhodospiraceae, DNA-DNA hybridization data were incomplete and limited to only four type strains (Ivanova et al., 1985); actually this experimental approach had never been applied to the delineation of species of this family. Therefore, DNADNA hybridization experiments have been performed on strains belonging to the genus Ectothiorhodospira, including all type strains of the species of this genus. Ribotype, another source of genotypic information, has been added to accumulate evidence for the detection of genotypic coherency at the species level. Following collection of this data, a revision of the species of the genus Ectothiorhodospira has been proposed by comparing all genotypic and phenotypic data currently available.

\section{METHODS}

Bacterial strains and growth conditions. Strains of the family Ectothiorhodospiraceae included in this study are listed in Table 1. Ectothiorhodospira mobilis DSM 237 , Ectothiorhodospira marina DSM $241^{\mathrm{T}}$ and Ectothiorhodospira marismortui EG- $1^{\mathrm{T}}$ were cultivated in a modified Pfennig's medium for purple sulfur bacteria (Malik, 1991), adjusting the salinity to the values indicated in Table 1 by using $\mathrm{NaCl}$. Strains of Ectothiorhodospira vacuolata were cultivated in original medium (Imhoff et al., 1981). The remaining strains of Ectothiorhodospira species and all strains of Halorhodospira species were cultivated in the medium originally designed for Halorhodospira halochloris (Imhoff \& Trüper, 1977), adjusting the salinity to the values indicated in Table 1 by using $\mathrm{NaCl} / \mathrm{Na}_{2} \mathrm{CO}_{3} / \mathrm{Na}_{2} \mathrm{SO}_{4}$ at a constant ratio $8: 1: 1$. All strains were grown anaerobically in the light at 20003000 lux and cells were harvested in the late exponential phase.

DNA extraction and purification. High-molecular-mass DNA was extracted from cell pellets with phenol/ chloroform and contaminating polysaccharides were removed with cetyltrimethylammonium bromide (CTAB) precipitation according to Ventura et al. (1993).

DNA-DNA hybridization. DNA-DNA hybridization was performed following the filter hybridization method of Hernandez et al. (1991) with some modifications (Surico et al., 1996). DNA stock solutions were prepared in $0.4 \mathrm{M}$ $\mathrm{NaOH}, 10 \mathrm{mM}$ EDTA, $\mathrm{pH}$ 8, adjusting the concentration to $20 \mu \mathrm{g} \mathrm{ml}^{-1}$. Samples for slot blots were prepared by diluting $25 \mu \mathrm{l}$ aliquots of stock solutions in $475 \mu \mathrm{l}$ of the same buffer. Three to six replicates of each DNA were denatured at $95-100{ }^{\circ} \mathrm{C}$ for $10 \mathrm{~min}$, rapidly cooled on ice and vacuumblotted onto Zeta-Probe nylon membrane using the Bio-Dot
SF apparatus (Bio-Rad). Blots were washed twice with $500 \mu \mathrm{l} 0.4 \mathrm{M} \mathrm{NaOH}$ and then the membrane was dried at $80^{\circ} \mathrm{C}$ for $30 \mathrm{~min}$. Prehybridization, hybridization and washes were carried out inside the glass tubes of a hybridization oven (HB-2D Hybridizer; Techne); the formamide protocol of the Zeta-Probe membrane instruction manual was used. The hybridization probes, consisting of genomic DNA, were labelled and detected with the digoxigenin labelling and detection kit (Boehringer Mannheim) following the instructions of the supplier. The probe was added to the hybridization solution at a final concentration of $0.2 \mu \mathrm{g} \mathrm{m} l^{-1}$. Hybridization under optimal conditions was performed at $47^{\circ} \mathrm{C}$. When a confirmation of phylogenetic relatedness was needed (Wayne et al., 1987), hybridization under stringent conditions was performed at $54{ }^{\circ} \mathrm{C}$, as an alternative to $\Delta T_{\mathrm{m}}$ determination (Stackebrandt \& Liesack, 1993; Surico et al., 1996). The mean absorbance of slot blots of each strain was obtained after scanning hybridized membranes with an LKB Ultroscan II laser densitometer. DNA reassociation was measured as the relative percentage of heterologous hybridization compared to homologous hybridization (100\%).

Ribotype. Ribotypes were performed according to Grimont et al. (1989). Aliquots of DNA (5 $\mu \mathrm{g})$ were digested overnight with $4 \mathrm{U}$ restriction endonuclease $(\mu \mathrm{g} \mathrm{DNA})^{-1}$ following the instructions of the supplier. DNA fragments were separated by $0.8 \%(\mathrm{w} / \mathrm{v})$ agarose gel electrophoresis in $1 \times$ Tris/borate buffer at $2 \mathrm{~V} \mathrm{~cm}^{-1}$ for $16 \mathrm{~h}$ (Grimont et al., 1989). Following electrophoresis, DNA fragments in the gel were depurinated for $30 \mathrm{~min}$ in $0.25 \mathrm{M} \mathrm{HCl}$, denatured for $30 \mathrm{~min}$ in $0.5 \mathrm{M}$ $\mathrm{NaOH}, 1.5 \mathrm{M} \mathrm{NaCl}$, neutralized for $1 \mathrm{~h}$ in $0.5 \mathrm{M}$ Tris $/ \mathrm{HCl}$, $\mathrm{pH} 7 \cdot 5,0.5 \mathrm{M} \mathrm{NaCl}$ and then transferred under low vacuum (Vacuum Blotter; Bio-Rad) to Hybond-N nylon membrane (Amersham) using $10 \times \mathrm{SSC}$ as transfer solution $(1 \times \mathrm{SSC}$ is $0 \cdot 15 \mathrm{M}$ sodium chloride, $0 \cdot 015 \mathrm{M}$ sodium citrate). After completion of transfer, the membrane was air-dried and baked for $2 \mathrm{~h}$ at $80^{\circ} \mathrm{C}$. Prehybridization, hybridization and washes were carried out, according to the acetylaminofluorene rRNA kit technical handbook (Eurogentec), inside the glass tubes of a hybridization oven (HB-2D Hybridizer; Techne). Hybridization was performed at $58{ }^{\circ} \mathrm{C}$ for $16 \mathrm{~h}$. Acetylaminofluorene-labelled $16 \mathrm{~S} / 23 \mathrm{~S}$ rRNA from Escherichia coli (Eurogentec) was used as hybridization probe. The immunoenzymic detection of hybridized fragments was performed with the acetylaminofluorene rRNA kit (Eurogentec). Hybridization profile images were captured as TIFF format files with a CCD camera (UVItec Gel Documentation System). Rescaling and normalization of electrophoretic band profiles, band detection, restriction profile comparison and clustering were performed with GelCompar 4.0 software (Applied Math) as described by Heyndrickx et al. (1996). The normalized profiles obtained with each of the five restriction endonucleases employed were assembled in the order given in Fig. 1, obtaining a single combined band pattern for each strain. Combined band patterns were subjected to pairwise comparison with the Dice similarity coefficient $\left(S_{\mathrm{D}}\right)$ and cluster analysis with UPGMA (Sneath \& Sokal, 1973).

\section{RESULTS \\ DNA-DNA reassociation}

Results of DNA-DNA hybridization experiments, performed under optimal $\left(47^{\circ} \mathrm{C}\right)$ or stringent $\left(54^{\circ} \mathrm{C}\right)$ conditions among strains of the family Ectothio- 
Table 1. Strains of Ectothiorhodospiraceae included in this study

Strains have been grouped following genospecies delineated by DNA-DNA reassociation, as discussed in the text. New names have been reported only for strains formally reassigned to a different species.

\begin{tabular}{|c|c|c|c|c|}
\hline Species & New assignment & Strain & $\begin{array}{l}\text { Growth } \\
\text { medium* }\end{array}$ & Source $\dagger$ \\
\hline E. vacuolata & E. shaposhnikovii & DSM $2111^{\mathrm{T}}$ & VA (3) & DSMZ \\
\hline E. vacuolata & E. shaposhnikovii & B3 & VA (3) & B. Tindall \\
\hline E. shaposhnikovii & & DSM $243^{\mathrm{T}}$ & EM (3) & DSMZ \\
\hline E. marismortui & E. mobilis & $\mathrm{EG}-1^{\mathrm{T}}$ & PM (10) & A. Oren \\
\hline Ectothiorhodospira sp. & E. mobilis & EST8 & EM (10) & Our laboratory \\
\hline E. mobilis & & $\operatorname{DSM} 237^{\mathrm{T}}$ & PM (3) & DSMZ \\
\hline E. mobilis & & DSM 240 & PM (3) & DSMZ \\
\hline E. marina & & $\operatorname{DSM} 241^{\mathrm{T}}$ & PM (3) & DSMZ \\
\hline E. haloalkaliphila & & $\mathrm{BN} 9903^{\mathrm{T}}$ & EM (5) & J. F. Imhoff \\
\hline H. halophila & & BN 9624 & EM (25) & J. F. Imhoff \\
\hline H. halophila & & DSM $244^{T}$ & EM (22) & DSMZ \\
\hline H. halophila & & BN 9630 & EM (15) & J. F. Imhoff \\
\hline H. halochloris & & BN 9851 & EM (15) & J. F. Imhoff \\
\hline H. halochloris & & BN 9852 & EM (15) & J. F. Imhoff \\
\hline H. abdelmalekii & & DSM $2110^{\mathrm{T}}$ & EM (15) & DSMZ \\
\hline
\end{tabular}

*VA, original E. vacuolata medium; EM, medium for H. halochloris; PM, modified Pfennig's medium. The percentage salinity (w/v) of the medium used for cultivation is indicated in parentheses. $\dagger$ DSMZ, Deutsche Sammlung von Mikroorganismen und Zellkulturen, Braunschweig, Germany; B. Tindall, DSMZ, Braunschweig, Germany; A. Oren, Institute of Life Sciences, The Hebrew University, Jerusalem, Israel; J. F. Imhoff, Institut für Meereskunde, Universität Kiel, Kiel, Germany.

rhodospiraceae are shown in Table 2. Membraneblotted DNAs were hybridized to DNA probes obtained from the type strains of all species of the genus Ectothiorhodospira and, for comparison, from Halorhodospira halophila BN 9630. Significant levels of hybridization were never detected in hybridizations between Ectothiorhodospira and Halorhodospira species. Probing membranes with DNA of either $E$. mobilis DSM $237^{\mathrm{T}}$ or E. marismortui EG-1 ${ }^{\mathrm{T}}$, DNA reassociation values above $84 \%$ were obtained with Ectothiorhodospira sp. strain EST8, E. mobilis DSM $237^{\mathrm{T}}$ and E. marismortui EG- $1^{\mathrm{T}}$. With the same DNA probes, other strains belonging to species of the genus Ectothiorhodospira gave hybridization values in the range 14-26\%. Ectothiorhodospira shaposhnikovii DSM $243^{\mathrm{T}}, E$. vacuolata DSM $2111^{\mathrm{T}}$ and E. vacuolata B3 also showed high reciprocal DNA reassociation values. The genotypic similarity between E. shaposhnikovii DSM $243^{\mathrm{T}}$ and E. vacuolata DSM $2111^{\mathrm{T}}$, measured under optimal conditions (70-80\%), was confirmed with hybridization performed under stringent conditions. DNA hybridization measurements between the recently described species E. marina and Ectothiorhodospira haloalkaliphila gave values slightly less than $40 \%$ under both optimal and stringent conditions. Hybridization of strains of Halorhodospira species to a DNA probe of Halorhodospira halophila BN 9630 (Table 2) resulted in strong signals from strains belonging to $H$. halophila and weak signals from strains belonging to the other halophilic species Halorhodospira abdelmalekii and H. halochloris.

\section{Ribotype}

Five sets of $16 \mathrm{~S} / 23 \mathrm{~S}$ rDNA RFLP (ribotype) data were obtained by digesting the DNA of strains of Ectothiorhodospira species with the restriction endonucleases KspI, NaeI, RsaI, SacI and TaqI. Electrophoretic bands of the KspI ribotype were distributed between 7 and $0.8 \mathrm{kbp}$; bands of the NaeI ribotype between 9.8 and $1.75 \mathrm{kbp}$; bands of the $R s a$ I ribotype between 2.6 and $0.35 \mathrm{kbp}$; bands of the $S a c$ I ribotype between 20 and $1.9 \mathrm{kbp}$ and bands of the TaqI ribotype between 1.3 and $0.3 \mathrm{kbp}$. The presence of highmolecular-mass bands in ribotypes obtained with endonucleases $\mathrm{NaeI}$ and $\mathrm{SacI}$ indicated that more than one ribosomal operon is present in the examined strains of Ectothiorhodospira. Hybridization patterns obtained with the five endonucleases were assembled to obtain a single combined restriction pattern for each strain of Ectothiorhodospira. A schematic representation of the composite band patterns is given in Fig. 1. The integration of single restriction profiles of the $16 \mathrm{~S} / 23 \mathrm{~S}$ rDNA in a unique composite pattern allowed 
Table 2. Levels of DNA-DNA hybridization between strains of Ectothiorhodospiraceae

DNA-DNA hybridization was measured under optimal $\left(47^{\circ} \mathrm{C}\right)$ or stringent $\left(54^{\circ} \mathrm{C}\right)$ conditions. Values are given \pm SD. Strains whose DNA was used as hybridization probe are indicated by their reference numbers reported in the first column of the table.

\begin{tabular}{|c|c|c|c|c|c|c|c|c|c|}
\hline \multirow[t]{2}{*}{ Source of unlabelled DNA } & \multicolumn{7}{|c|}{ Relative binding of probe DNA at $47^{\circ} \mathrm{C}(\%)$} & \multicolumn{2}{|c|}{$\begin{array}{l}\text { Relative binding } \\
\text { at } 54^{\circ} \mathrm{C}(\%)\end{array}$} \\
\hline & 1 & 3 & 4 & 6 & 7 & 8 & 11 & 3 & 8 \\
\hline $\begin{array}{l}\text { 1. E. vacuolata DSM } \\
2111^{\mathrm{T}}\end{array}$ & 100 & $70 \pm 3 \cdot 8$ & $21 \pm 5 \cdot 2$ & $18 \pm 6 \cdot 8$ & $11 \pm 3 \cdot 4$ & $9 \pm 1 \cdot 2$ & $2 \pm 0 \cdot 9$ & $100 \pm 4 \cdot 5$ & $5 \pm 2 \cdot 0$ \\
\hline 2. E. vacuolata B3 & $110 \pm 17 \cdot 1$ & & $26 \pm 2 \cdot 7$ & $25 \pm 8 \cdot 3$ & $11 \pm 3 \cdot 3$ & & $4 \pm 0 \cdot 8$ & $101 \pm 8 \cdot 7$ & $8 \pm 2 \cdot 6$ \\
\hline $\begin{array}{l}\text { 3. E. shaposhnikovii } \\
\text { DSM } 243^{\mathrm{T}}\end{array}$ & $80 \pm 17 \cdot 8$ & 100 & $14 \pm 0 \cdot 9$ & $14 \pm 5 \cdot 5$ & $10 \pm 1 \cdot 5$ & $8 \pm 1 \cdot 7$ & $3 \pm 0 \cdot 3$ & 100 & $6 \pm 0 \cdot 6$ \\
\hline 4. E. marismortui $\mathrm{EG}-1^{\mathrm{T}}$ & $40 \pm 11 \cdot 7$ & $26 \pm 10 \cdot 5$ & 100 & $120 \pm 10 \cdot 5$ & $27 \pm 9 \cdot 6$ & $15 \pm 2 \cdot 6$ & $7 \pm 0 \cdot 9$ & & \\
\hline $\begin{array}{l}\text { 5. Ectothiorhodospira } \\
\text { sp. EST8 }\end{array}$ & $29 \pm 7 \cdot 4$ & $36 \pm 4 \cdot 5$ & $96 \pm 19 \cdot 7$ & $90 \pm 6 \cdot 4$ & $15 \pm 5 \cdot 2$ & $11 \pm 1 \cdot 2$ & $7 \pm 0 \cdot 7$ & $14 \pm 4 \cdot 0$ & $5 \pm 1 \cdot 7$ \\
\hline 6. E. mobilis DSM $237^{\mathrm{T}}$ & $31 \pm 8 \cdot 1$ & $34 \pm 7 \cdot 0$ & $84 \pm 18 \cdot 0$ & 100 & $21 \pm 10 \cdot 2$ & $7 \pm 0 \cdot 0$ & $5 \pm 0.5$ & $15 \pm 1 \cdot 0$ & $4 \pm 0 \cdot 6$ \\
\hline 7. E. marina DSM $241^{\mathrm{T}}$ & $28 \pm 12 \cdot 4$ & $38 \pm 7 \cdot 2$ & $20 \pm 1 \cdot 8$ & $18 \pm 8 \cdot 4$ & 100 & $38 \pm 5 \cdot 9$ & $2 \pm 0 \cdot 3$ & $24 \pm 2 \cdot 0$ & $35 \pm 5 \cdot 0$ \\
\hline $\begin{array}{l}\text { 8. E. haloalkaliphila } \\
\text { BN } 9903^{\mathrm{T}}\end{array}$ & & $25 \pm 3 \cdot 2$ & & & & 100 & & $13 \pm 2 \cdot 0$ & 100 \\
\hline 9. H. halophila $\mathrm{BN} 9624$ & $3 \pm 1 \cdot 1$ & & $3 \pm 0 \cdot 7$ & $3 \pm 1 \cdot 3$ & $2 \pm 0 \cdot 5$ & & $85 \pm 22 \cdot 6$ & & \\
\hline $\begin{array}{l}\text { 10. H. halophila DSM } \\
244^{\mathrm{T}}\end{array}$ & $4 \pm 0 \cdot 9$ & & $5 \pm 0 \cdot 5$ & $2 \pm 0 \cdot 0$ & $1 \pm 0 \cdot 5$ & & $91 \pm 17 \cdot 4$ & & \\
\hline 11. H. halophila BN 9630 & $4 \pm 1 \cdot 2$ & & $3 \pm 0 \cdot 5$ & $2 \pm 1 \cdot 0$ & $1 \pm 0 \cdot 0$ & & 100 & & \\
\hline $\begin{array}{l}\text { 12. H. halochloris } \mathrm{BN} \\
9851\end{array}$ & $2 \pm 0.5$ & & $2 \pm 0 \cdot 5$ & $2 \pm 0 \cdot 6$ & $1 \pm 0 \cdot 0$ & & $6 \pm 0 \cdot 2$ & & \\
\hline $\begin{array}{l}\text { 13. H. halochloris } \mathrm{BN} \\
9852\end{array}$ & $2 \pm 0 \cdot 2$ & & $2 \pm 0 \cdot 6$ & $1 \pm 0 \cdot 5$ & $1 \pm 0 \cdot 1$ & & $5 \pm 0 \cdot 2$ & & \\
\hline $\begin{array}{l}\text { 14. H. abdelmalekii } \\
\text { DSM } 2110^{\mathrm{T}}\end{array}$ & $4 \pm 0 \cdot 8$ & & $3 \pm 0 \cdot 7$ & $2 \pm 0 \cdot 5$ & $5 \pm 1 \cdot 7$ & & $10 \pm 2 \cdot 3$ & & \\
\hline
\end{tabular}

the simultaneous examination of $19-32$ restriction sites. The application of the UPGMA clustering algorithm to the $S_{\mathrm{D}}$ value matrix obtained from pairwise comparison of composite patterns gave the dendrogram reported in Fig. 1. This showed the existence of groups of correlated or identical profiles. A cluster with an overall similarity of $63 \%$ contained two identical profiles belonging to strains of E. mobilis DSM $237^{\mathrm{T}}$ and DSM 240 joined to the two very similar profiles of E. marismortui EG-1 ${ }^{\mathrm{T}}$ and Ectothiorhodospira sp. EST8. E. vacuolata DSM $2111^{\mathrm{T}}$ and B3 had identical profiles that clustered at $58 \%$ similarity with the profile of E. shaposhnikovii DSM $243^{\mathrm{T}}$. Profiles of E. marina DSM $241^{\mathrm{T}}$ and E. haloalkaliphila $\mathrm{BN} 9903^{\mathrm{T}}$ were more loosely related at $50 \%$ similarity.

\section{DISCUSSION}

DNA reassociation has been considered to be the nearest approximation of the complete genome sequence that is practically applicable to the definition of the bacterial species in phylogenetic terms (Wayne et al., 1987). Even if there is no absolute definition of any taxonomic rank in any branch of biology, on the basis of the high degree of correlation between DNA relatedness and other genotypic and phenotypic characters that was found in numerous studies, a threshold of $70 \%$ DNA-DNA relatedness among strains belonging to the same bacterial species has been indicated. This historical recommendation has not yet been updated by the discovery of other more specific quantitative approaches and is still applied when related bacterial strains have to be subdivided into different species (Stackebrandt \& Goebel, 1994). For this reason we measured total DNA hybridization among a larger number of strains of the family Ectothiorhodospiraceae than previously done (Ivanova et al., 1985). A second reason that underpins the present study is the incomplete comparison of proposed new species and of their type strains with the type strains of described species. Following a more rigorous taxonomic practice, we included all type strains of the species of Ectothiorhodospira in the experimental approach described in this work and critically reviewed the pertinent literature, discriminating the taxonomic statements which were based on comparisons with type strains from those that were not.

As shown in Table 2, very low DNA-DNA hybridization values clearly set apart strains belonging to the genus Halorhodospira from strains belonging to the genus Ectothiorhodospira, confirming the phylo- 

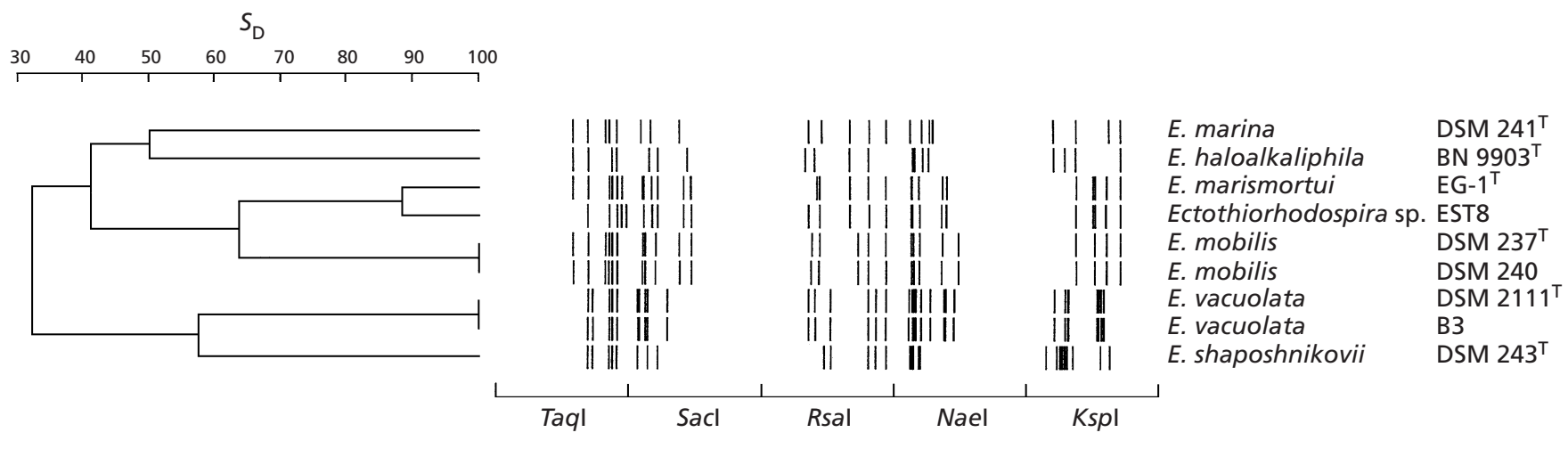

Fig. 1. Ribotype of Ectothiorhodospira species. Right: composite restriction profiles of $16 \mathrm{~S} / 23 \mathrm{~S}$ rDNA (ribotype) of strains of Ectothiorhodospira species. The scheme of the combined band patterns, obtained with GelCompar software, of five ribotype patterns generated with the restriction enzymes indicated is shown. Left: dendrogram of UPGMA cluster analysis of the combined ribotype band patterns.

genetic divergence of the two groups of anoxygenic phototrophic bacteria shaping the family Ectothiorhodospiraceae. Even if strains of the genus Halorhodospira had been included in this study only for outgroup reference purposes, it is evident that the three strains of $H$. halophila examined formed a coherent genospecies, well separated from strains belonging to the other highly halophilic species $H$. halochloris and H. abdelmalekii. However, a detailed investigation of the taxonomy of the species of Halorhodospira is beyond the scope of this report and will deserve a new specific study.

From the results of DNA-DNA hybridization experiments reported in Table 2, including all the type strains of the six Ectothiorhodospira species presently described, four genospecies of Ectothiorhodospira were detected by the application of a $70 \%$ DNA relatedness lower limit for strains belonging to the same species. Strains of E. vacuolata and E. shaposhnikovii DSM $243^{\mathrm{T}}$ make up a single genospecies; E. mobilis DSM $237^{\mathrm{T}}$, E. marismortui EG- $1^{\mathrm{T}}$ and strain EST8 form another genospecies; while the type strains of the remaining two species of Ectothiorhodospira, E. marina DSM $241^{\mathrm{T}}$ and E. haloalkaliphila BN $9903^{\mathrm{T}}$, constitute the other two genospecies. There is thus an indication that only four out of the six species presently described could be delineated in the genus Ectothiorhodospira on the basis of DNA relatedness measurements on the type strains and on other available strains.

Since a taxonomic study should be always performed with a combination of several approaches, other knowledge on the genotypic relatedness of strains of Ectothiorhodospira was obtained from RFLP data of the rRNA operon (ribotype). Cluster analyses performed on composite profiles showed the existence of groups of related strains that corresponded to the genospecies delineated by DNA-DNA hybridization measurements. This observation partially confirmed the analysis of the 16S rRNA sequences performed by Imhoff \& Süling (1996), that showed the existence of clusters of sequences related at similarities of $98 \cdot 22 \%$ and higher (E. shaposhnikovii-E. vacuolata cluster) and $97.93 \%$ and higher (E. marina-E. haloalkaliphila cluster). In contrast with the experimental results shown in this study and with published characterization studies discussed below, 16S rRNA sequence analysis performed by Imhoff \& Süling (1996) placed strain E. mobilis DSM $237^{\mathrm{T}}$ in a branch of the phylogenetic tree separated from all other analysed strains of the genus Ectothiorhodospira. In this regard, analysing the same gene but with a different experimental approach, namely the restriction profiles of the amplified 16S rRNA gene (ARDRA) (Ventura et al., 1998), we obtained strong evidence of a tight similarity between profiles of E. mobilis DSM $237^{\mathrm{T}}$ and of $E$. marismortui. High similarities of ARDRA profiles should correspond to high 16S rRNA sequence similarities, but in the case of strains DSM $237^{\mathrm{T}}$ and EG-1 ${ }^{\mathrm{T}}$ this was not true. It seemed to us to be opportune to trust the ARDRA data. These data were in total agreement with all other genotypic and phenotypic data, as discussed below.

The comprehensive comparison of DNA relatedness analysis and ribotype data presented in this study with sequence and ARDRA data, in our opinion, confirms the existence of four genospecies of Ectothiorhodospira. The single genospecies are examined below to verify if they could be differentiated by congruent phenotypic properties, thus allowing the delineation of taxonomically meaningful species.

\section{E. mobilis - E. marismortui - strain EST8}

The soundness of this genospecies, already defined by the high-level DNA relatedness shared by E. mobilis DSM $237^{\mathrm{T}}$, E. marismortui EG- $1^{\mathrm{T}}$ and strain EST8, was emphasized by ribotype (Fig. 1), ARDRA (Ventura et al., 1998) and by total DNA restriction pattern analysis (Ventura et al., 1993). This genospecies definitely also contains strain DSM 240 that 
shared identical ribotype (Fig. 1) and ARDRA profiles (Ventura et al., 1998) with E. mobilis DSM 237 , and strain DSM 238 that shared an identical ARDRA profile with E. mobilis DSM $237^{\mathrm{T}}$ (Ventura et al., 1998). As cited by Thiemann \& Imhoff (1996) for many strains of Ectothiorhodospira and Halorhodospira species, members of this genospecies have a $\mathrm{G}+\mathrm{C}$ content in the range $65-68 \mathrm{~mol} \%$, around $5 \%$ higher than that of the other species of Ectothiorhodospira. Members of this genospecies are intermediate saltrequiring strains isolated from different marine or hypersaline environments (Trüper, 1968; Oren et al., 1989; Ventura et al., 1988). Chemotaxonomic character consistency among strains is remarkably high. Strains E. mobilis DSM 237 ${ }^{\mathrm{T}}$, DSM 238 and DSM 240, and E. marismortui EG- ${ }^{\mathrm{T}}$ are members of fatty acid cluster V (Thiemann \& Imhoff, 1996); E. mobilis DSM $237^{\mathrm{T}}$, E. marismortui EG- ${ }^{\mathrm{T}}$ and strain EST8 have the same quinone complement (Ventura et al., 1993). Strains belonging to this genospecies have corresponding morphological and ultrastructural characters, growth requirements and pigments. Comparing the formal description of E. mobilis (Trüper, 1968; Imhoff, 1989 ) to the characterization study of E. marismortui EG- $1^{\mathrm{T}}$ (Oren et al., 1989), it is evident that this latter strain fits nicely into the description of E. mobilis, with three exceptions: 16S rRNA oligonucleotide catalogue data (Stackebrandt et al., 1984), polar lipid composition and compatible solutes. Indeed, the $16 \mathrm{~S}$ rRNA oligonucleotide catalogue of strain EG-1 ${ }^{\mathrm{T}}$ had not been compared with the type strain of E. mobilis nor with any other strain of this species, since, as recently demonstrated (Imhoff \& Süling, 1996), strain BN 9903, included in the oligonucleotide catalogue study as representative of the species E. mobilis, does not belong to it. Conversely, the global genomic relatedness of strain EG- $1^{\mathrm{T}}$ to E. mobilis is warranted by DNA-DNA hybridization and also by ribotype and ARDRA. Also, the phenotypic traits claimed to support the separation of strain EG- $1^{\mathrm{T}}$ from E. mobilis cannot be used for this scope, since phospholipids have been studied in the so-called E. mobilis strain BN 9903 (Asselineau \& Trüper, 1982; Imhoff et al., 1982a; Thiemann \& Imhoff, 1991) and no report has been published dealing with compatible solutes of strain DSM $237^{\mathrm{T}}$, the type strain of E. mobilis. In consideration of the strong genotypic coherence of the strains of this genospecies and of the prevalence of common phenotypic traits, we propose that this genospecies deserves the rank of taxonomic species. In this respect, strain $\mathrm{EG}-1^{\mathrm{T}}$, previously assigned to E. marismortui as the type strain of the species, is recognized as a strain of $E$. mobilis, since the name E. mobilis, included in the Approved Lists of Bacterial Names (Skerman et al., 1980), has priority over the species name E. marismortui subsequently validly published (Oren et al., 1990). As a consequence of renaming the type strain of the species, the binomial Ectothiorhodospira marismortui should be considered as a junior subjective synonym of Ectothiorhodospira mobilis. A slightly emended description of E. mobilis that reflects the assignment of strains EG-1 and EST8 to this species is given below.

\section{E. shaposhnikovii - E. vacuolata}

DNA-DNA hybridization values measured under optimal conditions between strains of E. vacuolata and E. shaposhnikovii DSM $243^{\mathrm{T}}$ (Table 2) were found to be toward the lower borderline of the suggested relatedness among members of the same species (Wayne et al., 1987). The taxonomic significance of the DNA reassociation value of $70 \%$ between $E$. shaposhnikovii DSM $243^{\mathrm{T}}$ probe DNA and E. vacuolata DSM $2111^{\mathrm{T}}$ has been approached by hybridization measurements performed under stringent conditions (Table 2). The obtained values delineated a strong genomic relatedness between strains of E. vacuolata and E. shaposhnikovii DSM $243^{\mathrm{T}}$ that is confirmed, as already discussed, by ribotype, ARDRA (Ventura et al., 1998) and 16S rRNA analysis (Imhoff \& Süling, 1996). By reviewing previously published literature dealing with these anoxyphototrophic bacteria, this group of three strains revealed a remarkable degree of phenotypic consistency. All three strains belong to the same fatty acid cluster (Thiemann \& Imhoff, 1996) and have the same quinone content (Imhoff, 1984b; Ventura et al., 1993). Lipopolysaccharides of $E$. shaposhnikovii DSM $243^{\mathrm{T}}$ and E. vacuolata DSM $2111^{\mathrm{T}}$ are very similar and, in particular, a high degree of similarity is shown by the fatty acid composition of their lipid A moieties (Meißner et al., 1988; Zahr et al., 1992). In finding that porins of E. shaposhnikovii and E. vacuolata were unusually conserved, Wolf et al. (1996) observed that they were actually more similar to each other than porins isolated from two bacterial strains belonging to the same species, Rhodobacter capsulatus. Other morphological and physiological characters, as summarized by the respective species descriptions given in Bergey's Manual of Systematic Bacteriology (Imhoff, 1989) are nearly identical; minor differences can only be detected in cell diameter and nitrate assimilation. The only significant difference between E. vacuolata and E. shaposhnikovii is the presence, in some growth conditions, of gas vesicles in E. vacuolata strains DSM $2111^{\mathrm{T}}$ and B3 (Imhoff et al., 1981). In our opinion this character alone, like any other character alone, cannot be invoked to justify the separation of three strains that are otherwise very similar. In any case, gas vesicle genes are often located on plasmids and cannot therefore be regarded as stable features as chromosomal genes are. The three examined strains, E. vacuolata DSM $2111^{\mathrm{T}}$, B3 and $E$. shaposhnikovii DSM $243^{\mathrm{T}}$, having been recognized as members of a genomic cluster showing strong phenotypic consistency, should therefore be regarded as members of the same species. Strains DSM 2111 and B3, previously assigned to E. vacuolata, are thus proposed to be strains of E. shaposhnikovii, since the name E. shaposhnikovii, included in the Approved Lists of Bacterial Names (Skerman et al., 1980), has priority over the species name E. vacuolata subse- 
quently validly published (Imhoff et al., 1982b). As a consequence of renaming the type strain of the species, the binomial Ectothiorhodospira vacuolata should be considered as a junior subjective synonym of Ectothiorhodospira shaposhnikovii. A slightly emended description of E. shaposhnikovii that reflects the assignment of vacuolated strains to this species is given below.

\section{Other Ectothiorhodospira species}

The genetic relatedness between the two genospecies constituted by the two strains E. marina DSM $241^{\text {T }}$ and E. haloalkaliphila BN $9903^{\mathrm{T}}$, measured as DNA reassociation, steadily maintained a value of about $38 \%$ measured under optimal or stringent conditions (Table 2). This level of genomic relatedness, higher than among the other Ectothiorhodospira species, is also supported by $16 \mathrm{~S}$ rRNA sequence similarity (Imhoff \& Süling, 1996) and by quinone (Ventura et $a l ., 1993)$ and fatty acid (Thiemann \& Imhoff, 1996) contents. These two species are remarkably related but, at present, no clear cut evidence is available, especially at the genome level, that could induce a reconsideration of their taxonomic status.

\section{Concluding remarks}

From the results presented in this paper, the empirical $70 \%$ DNA hybridization value suggested as a borderline for the attribution of strains to the same bacterial species nicely fits the revised species subdivision of the genus Ectothiorhodospira that has been obtained through a combination of genotypic and phenotypic properties (polyphasic taxonomy). Holding its general validity also for this group of anoxygenic phototrophic bacteria, DNA reassociation should be therefore inserted in the list of the minimum standards required for the description of new species presently under preparation by the International Committee on Systematic Bacteriology, Subcommittee on the taxonomy of phototrophic bacteria (International Journal of Systematic Bacteriology, 1999).

Up to now, species of the genus Ectothiorhodospira have been described on the basis of only one or a few strains. Of course this impairs not only the identification of widespread features acting as signatures of single species but also the establishment of the borderline between infraspecific and interspecific variability (Vandamme et al., 1996) that is necessary for a correct taxonomic assessment. In our opinion, the concept of bacterial species includes strains with a limited degree of genetic diversity that is also reflected in some variation in secondary phenotypic traits. These phenotypically very similar strains, that are not clonal, make up the so-called infraspecific biodiversity (Harper \& Hawksworth, 1995; O'Donnell et al., 1995), the ultimate source of adaptation of the bacterial species to microhabitats. Their systematic study is the only way to identify key phenotypic traits to be coupled with genetic characterization in the diagnostic description of a species. This should be considered when describing new species.

\section{Emended description of Ectothiorhodospira mobilis Pelsh 1936}

Ectothiorhodospira mobilis (mo'bi.lis. L. adj. mobilis mobile).

Cells are vibrioid-shaped or curved in a short spiral or rod-shaped, usually slightly bent, $0 \cdot 7-1 \cdot 3 \mu \mathrm{m}$ wide and $1.5-3.3 \mu \mathrm{m}$ long; multiplication is by binary fission. Cells are motile by means of a polar tuft of flagella and are Gram-negative. Intracytoplasmic membrane system is present as lamellar stacks. Colour of cell suspensions that are free of polysulfides and elemental sulfur is red-purple. In vivo absorption spectra show maxima at 378, 488, 516, 550, 590, 796, 858 and 888 (shoulder) $\mathrm{nm}$. Photosynthetic pigments are bacteriochlorophyll $a$ (esterified with phytol) and carotenoids of the spirilloxanthin series. Cells grow anaerobically under phototrophic conditions with reduced sulfur compounds or organic carbon sources as electron donor. Photoautotrophic growth is possible with sulfide and elemental sulfur; some strains also use thiosulfate and sulfite. Acetate, pyruvate, malate, succinate and fumarate are used as organic carbon source and electron donor. Some strains also use fructose, glucose, lactate, butyrate and propionate. Ammonia, $\mathrm{N}_{2}$ and some amino acids are used as nitrogen source. Sulfate can be used by some strains as sole sulfur source. Vitamin $\mathrm{B}_{12}$ or small concentrations of yeast extract enhance growth of some strains. Optimal growth is at $25-40{ }^{\circ} \mathrm{C}, \mathrm{pH} 7-8$ and $2-10 \%$ salt. Major quinone components are MK-7 and Q-8. The $\mathrm{G}+\mathrm{C}$ content of the DNA is $67.3-68.4 \mathrm{~mol} \%$ (Bd) and $65 \mathrm{~mol} \%\left(T_{\mathrm{m}}\right)$. Type strain is DSM $237^{\mathrm{T}}$ $\left(=\right.$ Trüper $\left.8112^{\mathrm{T}}\right)$. Other strains include DSM 4180 (= Oren EG-1), EST8.

\section{Emended description of Ectothiorhodospira shaposhnikovii Cherni, Solovieva, Fedorova and Kondratieva 1969}

Ectothiorhodospira shaposhnikovii (sha.posh.ni.ko'vi.i. M.L. gen. n. shaposhnikovii of Shaposhnikov, after D. I. Shaposhnikov, a Russian microbiologist).

Cells are rod-shaped, usually slightly bent; with propionate as carbon source, they have a vibrioid or short spirillar shape and are $0.8-1.5 \mu \mathrm{m}$ wide and $1.5-4.0 \mu \mathrm{m}$ long, motile by means of a tuft of polar flagella, divide by binary fission and are Gramnegative. Some strains can develop gas vesicles in the motile stage of growth, in the following stage vacuolated cells become immotile and float to the top; at low sulfide concentrations and low light intensities motile non-vacuolated cells predominate; stationary phase cells generally become immotile and vacuolated. Cell dimensions are usually larger in vacuolated strains 
than in non-vacuolated. Internal photosynthetic membranes are present as lamellar stacks. Colour of cell suspensions in the absence of polysulfides and elemental sulfur is red. Absorption spectra of living cells show maxima at 378, 488, 516, 550, 590, 798 and $854 \mathrm{~nm}$. Photosynthetic pigments are bacteriochlorophyll $a$ (esterified with phytol) and carotenoids of the spirilloxanthin series with spirilloxanthin as the major component. Cells preferably grow under anaerobic conditions in the light. Photoautotrophic growth is possible with reduced sulfur compounds, elemental sulfur or $\mathrm{H}_{2}$ as electron donor. Chemoautotrophic and chemoheterotrophic growth is possible under microaerobic conditions in the dark. The photosynthetic electron donors and carbon sources used are sulfide, elemental sulfur, thiosulfate, sulfite, $\mathrm{H}_{2}$, acetate, propionate, butyrate, lactate, pyruvate, malate, succinate, fumarate and fructose. Formate, methanol, ethanol, glycerol, citrate and benzoate are not used. Ammonia, $\mathrm{N}_{2}$, nitrate and some amino acids are used as nitrogen source. Sulfate is used as sulfur source under photoheterotrophic conditions; some strains, not using sulfate, use cysteine and methionine instead. Growth factors are not required. Optimal growth is at $30-40{ }^{\circ} \mathrm{C}, \mathrm{pH} 7 \cdot 5-9 \cdot 5$ and $1-7 \%$ salt. Major quinone components are Q-7 and MK-7 (MK$6)$. The $\mathrm{G}+\mathrm{C}$ content of the DNA is $61 \cdot 4-63.6\left(T_{\mathrm{m}}\right)$. Type strain is DSM $243^{\mathrm{T}}\left(=\right.$ Kondratieva $\left.\mathrm{N}^{\mathrm{T}}\right)$. Other strains include DSM 2111 and B3 (both vacuolated).

\section{ACKNOWLEDGEMENTS}

J. F. Imhoff, A. Oren and B. Tindall are thanked for the gift of bacterial strains. The critical reading of the manuscript by E. Stackebrandt is gratefully acknowledged.

\section{REFERENCES}

Asselineau, J. \& Trüper, H. G. (1982). Lipid composition of six species of the phototrophic bacterial genus Ectothiorhodospira. Biochim Biophys Acta 712, 111-116.

Cherni, N. E., Solovieva, Z. V., Fedorova, V. D. \& Kondratieva, E. N. (1969). Ultrastructure of cells of two species of purple sulfur bacteria. Mikrobiologiya 38, 479-484 (in Russian).

Clayton, R. A., Sutton, G., Hinkle, P. S., Jr, Bult, C. \& Fields, C. (1995). Intraspecific variation in small-subunit rRNA sequences in GenBank: why single sequences may not adequately represent prokaryotic taxa. Int J Syst Bacteriol 45, 595-599.

Fox, G. E., Wisotzkey, J. D. \& Jurtshuk, P. J. (1992). How close is close: 16S rRNA sequence identity may not be sufficient to guarantee species identity. Int J Syst Bacteriol 42, 166-170.

Grimont, F., Chevrier, D., Grimont, P. A. D., Lefevre, M. \& Guesdon, J.-L. (1989). Acetylaminofluorene-labelled ribosomal RNA for use in molecular epidemiology and taxonomy. Res Microbiol 140, 447-454.

Harper, J. L. \& Hawksworth, D. L. (1995). Preface. In Biodiversity. Measurement and Estimation, pp. 5-12. Edited by D. L. Hawksworth. London: Chapman \& Hall.

Hernandez, J., Owen, R. J., Costas, M. \& Lastovica, A. (1991). DNA-DNA hybridization and analysis of restriction endonuclease and rRNA gene patterns of atypical (catalase-weak/ negative) Campylobacter jejuni from paediatric blood and faecal cultures. J Appl Bacteriol 70, 71-80.

Heyndrickx, M., Vauterin, L., Vandamme, P., Kersters, K. \& De Vos, P. (1996). Applicability of combined amplified ribosomal DNA restriction analysis (ARDRA) patterns in bacterial phylogeny and taxonomy. J Microbiol Methods 26, 247-259.

Imhoff, J. F. (1984a). Reassignment of the genus Ectothiorhodospira Pelsh 1936 to a new family, Ectothiorhodospiraceae fam. nov., and emended description of the Chromatiaceae Bavendamm 1924. Int J Syst Bacteriol 34, 338-339.

Imhoff, J. F. (1984b). Quinones of phototrophic purple bacteria. FEMS Microbiol Lett 25, 85-89.

Imhoff, J. F. (1989). Genus Ectothiorhodospira Pelsh 1936, $120^{\mathrm{AL}}$. In Bergey's Manual of Systematic Bacteriology, vol. 3, pp. 1654-1658. Edited by J. T. Staley, M. P. Bryant, N. Pfennig \& J. G. Holt. Baltimore: Williams \& Wilkins.

Imhoff, J. F. \& Süling, J. (1996). The phylogenetic relationship among Ectothiorhodospiraceae: a re-evaluation of their taxonomy on the basis of $16 \mathrm{~S}$ rDNA analyses. Arch Microbiol 165, 106-113.

Imhoff, J. F. \& Trüper, H. G. (1977). Ectothiorhodospira halochloris sp. nov., a new extremely halophilic phototrophic bacterium containing bacteriochlorophyll b. Arch Microbiol 114, 115-121.

Imhoff, J. F., Tindall, B. J., Grant, W. D. \& Trüper, H. G. (1981). Ectothiorhodospira vacuolata sp. nov., a new phototrophic bacterium from soda lakes. Arch Microbiol 130, 238-242.

Imhoff, J. F., Kushner, D. J., Kushwaha, S. C. \& Kates, M. (1982a). Polar lipids in phototrophic bacteria of the Rhodospirillaceae and Chromatiaceae families. J Bacteriol 150, 1192-1201.

Imhoff, J. F., Tindall, B. J., Grant, W. D. \& Trüper, H. G. (1982b). Ectothiorhodospira vacuolata $\mathrm{sp}$. nov. In Validation of the Publication of New Names and New Combinations Previously Effectively Published Outside the IJSB, List No. 8. Int J Syst Bacteriol 32, 266-268.

International Journal of Systematic Bacteriology (1999). International Committee on Systematic Bacteriology: Subcommittee on the taxonomy of phototrophic bacteria. Minutes of the Meeting, 10 September 1997, Vienna, Austria. Int J Syst Bacteriol 49, 925-926.

Ivanova, T. L., Turova, T. P. \& Antonov, A. S. (1985). DNA-DNA and rRNA-DNA hybridization studies in the genus Ectothiorhodospira and other purple sulfur bacteria. Arch Microbiol 143, 154-156.

Malik, K. A. (1991). Maintenance of phototrophic bacteria. In Maintenance of Microorganisms and Cultured Cells, 2nd edn, pp. 81-100. Edited by B. E. Kirsop \& A. Doyle. London: Academic Press.

Meißner, J., Borowiak, D., Fischer, U. \& Weckesser, J. (1988). The lipopolysaccharide of the phototrophic bacterium Ectothiorhodospira vacuolata. Arch Microbiol 149, 245-248.

Murray, R. G. E., Brenner, D. J., Colwell, R. R., De Vos, P., Goodfellow, M., Grimont, P. A. D., Pfennig, N., Stackebrandt, E. \& Zavarzin, G. A. (1990). Report of the ad hoc committee on approaches to taxonomy within the Proteobacteria. Int $J$ Syst Bacteriol 40, 213-215.

O’Donnell, A. G., Goodfellow, M. \& Hawksworth, D. L. (1995). Theoretical and practical aspects of the quantification of biodiversity among microorganisms. In Biodiversity. Measurement and Estimation, pp. 65-73. Edited by D. L. Hawksworth. London: Chapman \& Hall.

Oren, A., Kessel, M. \& Stackebrandt, E. (1989). Ectothiorhodospira 
marismortui sp. nov., an obligately anaerobic, moderately halophilic purple sulfur bacterium from a hypersaline sulfur spring on the shore of the Dead Sea. Arch Microbiol 151, 524-529.

Oren, A., Kessel, M. \& Stackebrandt, E. (1990). Ectothiorhodospira marismortui sp. nov. In Validation of the Publication of New Names and New Combinations Previously Effectively Published Outside the IJSB, List No. 32. Int J Syst Bacteriol 40, 105-106.

Pelsh, A. D. (1936). Hydrobiology of Karabugaz. Trud Solyan Lab Akad Nauk SSSR (Moscow) 5, 49-80 (in Russian).

Pelsh, A. D. (1937). Photosynthetic sulfur bacteria of the eastern reservoir of Lake Sakskoe. Mikrobiologiya 6, 1090-1100 (in Russian).

Raymond, J. C. \& Sistrom, W. R. (1969). Ectothiorhodospira halophila: a new species of the genus Ectothiorhodospira. Arch Mikrobiol 69, 121-126.

Skerman, V. B. D., McGowan, V. \& Sneath, P. H. A. (1980). Approved lists of bacterial names. Int $J$ Syst Bacteriol 30, 225-420.

Sneath, P. H. A. \& Sokal, R. R. (1973). Numerical Taxonomy: the Principles and Practice of Numerical Classification. San Francisco: W. H. Freeman.

Stackebrandt, E. \& Goebel, B. M. (1994). Taxonomic note: a place for DNA-DNA reassociation and 16S rRNA sequence analysis in the present species definition in bacteriology. Int $J$ Syst Bacteriol 44, 846-849.

Stackebrandt, E. \& Liesack, W. (1993). Nucleic acids and classification. In Handbook of New Bacterial Systematics, pp. 151-194. Edited by M. Goodfellow \& A. G. O'Donnell. London: Academic Press.

Stackebrandt, E., Fowler, V. J., Shubert, W. \& Imhoff, J. F. (1984). Towards a phylogeny of phototrophic purple sulfur bacteria the genus Ectothiorhodospira. Arch Microbiol 137, 366-370.

Surico, G., Mugnai, L., Pastorelli, R., Giovannetti, L. \& Stead, D. E. (1996). Erwinia alni, a new species causing bark cankers of alder (Alnus Miller) species. Int J Syst Bacteriol 46, 720-726.

Thiemann, B. \& Imhoff, J. F. (1991). The effect of salt on the lipid composition of Ectothiorhodospira. Arch Microbiol 156, 376-384.

Thiemann, B. \& Imhoff, J. F. (1996). Differentiation of Ectothiorhodospiraceae based on their fatty acid composition. Syst Appl Microbiol 19, 223-230.

Trüper, H. G. (1968). Ectothiorhodospira mobilis Pelsh, a photosynthetic sulfur bacterium depositing sulfur outside the cells. J Bacteriol 95, 1910-1920.

Vandamme, P., Pot, B., Gillis, M., De Vos, P., Kersters, K. \& Swings, J. (1996). Polyphasic taxonomy, a consensus approach to bacterial systematics. Microbiol Rev 60, 407-438.

Ventura, S., De Philippis, R., Materassi, R. \& Balloni, W. (1988). Two halophilic Ectothiorhodospira strains with unusual morphological, physiological and biochemical characters. Arch Microbiol 149, 273-279.

Ventura, S., Giovannetti, L., Gori, A., Viti, C. \& Materassi, R. (1993). Total DNA restriction pattern and quinone composition of members of the family Ectothiorhodospiraceae. Syst Appl Microbiol 16, 405-410.

Ventura, S., Bruschettini, A., Giovannetti, L. \& Viti, C. (1998). Criteria for species delineation in the Ectothiorhodospiraceae. In The Phototrophic Prokaryotes, pp. 775-780. Edited by G. A. Peschek, W. Löffelhardt \& G. Schmetterer. New York: Plenum.

Wayne, L. G., Brenner, D. J., Colwell, R. R. \& 9 other authors (1987). International Committee on Systematic Bacteriology. Report of the ad hoc committee on reconciliation of approaches to bacterial systematics. Int J Syst Bacteriol 37, 463-464.

Wolf, E., Zahr, M., Benz, R., Imhoff, J. F., Lustig, A., Schiltz, E., Stahl-Zeng, J. \& Weckesser, J. (1996). The porins from the halophilic species Ectothiorhodospira shaposhnikovii and Ectothiorhodospira vacuolata. Arch Microbiol 166, 169-175.

Zahr, M., Fobel, B., Mayer, H., Imhoff, J. F., Campos, P. V. \& Weckesser, J. (1992). Chemical composition of the lipopolysaccharides of Ectothiorhodospira shaposhnikovii, Ectothiorhodospira mobilis, and Ectothiorhodospira halophila. Arch Microbiol 157, 499-504. 